\title{
Ammatilliset aikuiskoulutuskeskukset koulutusmarkkinoiden peilinä
}

\author{
Tapio Varmola 1994. Aikuiskoulutuksen muutoksen hallinta: esimerkkinä Vaasan \\ ammatillinen aikuiskoulutuskeskus. Tampereen yliopiston täydennyskoulutuskeskus. \\ Julkaisusarja A2/1994.
}

Tapio Varmola \& Marjatta Jokisuu 1995. Ammatillisten aikuiskoulutuskeskusten sisäinen ja ulkoinen muutos: tutkimus toimintastrategioista Raahen, Tampereen ja Yläsavon seuduilla. Tampereen yliopisto. Kasvatustieteiden laitos. Julkaisusarja A, n:o 54/1995.

Tapio Varmolan tutkimushanke ammatillisten aikuiskoulutuskeskusten muutoksen selvittämiseksi on tuottanut nyt kahden raportin verran tekstiä ja tuloksia. Tutkimusten kohteena on aikuiskoulutuskeskusten toiminnan sisäinen ja keskusten toimintaympäristön muutos ja tarkastelunäkökulmana suomalaisen aikuiskoulutuksen siirtyminen 1980-luvulta lähtien perusteiltaan markkinaohjautuvaksi. Raporteista ensimmäinen, vaikkakin sinänsä itsenäinen kokonaisuus, on yhden keskuksen esimerkillä valaistu ongelmakentän ja ajattelutavan esittely ja toinen, yhdessä Marjatta Jokisuun kanssa kirjoitettu, tarkastelee useamman tutkimuskohteen kautta vertaillen ammatillisten aikuiskoulutuskeskusten kulttuurimuutosta.

Ammatillisista aikuiskoulutuskeskuksista on kohtalaisen niukasti analyyttistä tutkimustietoa ja tutkimushanke osuu siten uteliaisuutta herättävään alueeseen. Tutkimuskohde on myös koulutuspoliittisesti perusteltu: ammatillisten kurssikeskusten muuttuminen ammatillisiksi aikuiskoulutuskeskuksiksi ei näytä olleen pelkkä nimenmuutos ja kielipeli, vaan instituutioiden toimintalogiikassa on tapahtunut muutoksia, jotka koulutus- ja yhteiskuntapolitiikan tasolla esimerkittävät siirtymää virastojohtoisuudesta kohti markkinajohtoisuutta.

Tutkimusaineisto on koottu haastatteluin kolmesta ryhmästä: keskusten henkilökunta, kilpailijaorganisaatioiden johtavat viranhaltijat ja sidosryhmät, joita tutkimuksessa ovat kuntien ja kuntainliittojen vaikuttajat sekä työvoimapiirien ja lääninhallitusten virkamiehet. Ratkaisu on tyylikkäästi perusteltu. Muodikas itsearviointinäkökulma toteutuu organisaation omien asiantuntijoiden suorittamassa evaluoinnissa ja kilpailijoiden sekä muiden ulkopuolisten haastattelut tuovat kiintoisaa täydennystä ja tulkinnallisia vivahteita.

Pitäytyminen evaluaationäkökulmaan on kuitenkin johtanut tutkimusteeman rajaukseen tavalla, jossa ei voida jäljittää ammatillisen aikuiskoulutuksen koulutussosiologisia luonteenpiirteitä, vaan pelkästään markkinavetoisuuden läpäisyä ja keskusten strategista ajankohtaistilannetta. Koulutusmarkkinoiden tarkastelu ja kulttuurimuutoksen dokumentointi on hyvin hyödyllistä koulutuspoliittista ja koulutussuunnittelullista taustatietoa, mutta tutkimuksellinen intensiteetti puolestaan saisi lisää voimia syvemmästä ammatillisen koulutuksen yhteiskuntatieteellisestä analyysistä mukaanlukien koulutuksen talouden.

Haastatteluaineisto herättää kysymyksen "puhunnan" tulkitsemisesta. Analyysi voi jäädä pelkästään vastaajien puheen suoraksi lainaamiseksi. Tutkijat kieltämättä erittelevät eri vastaajaryhmien intrigejä ja saamiensa vastausten ristiriitoja, mutta virtaviivaisia menetelmäkeskusteluviitteitä ja pohdiskelevia vastausten taustatulkintoja toivoisi olevan enemmänkin tarkastelua rikastamassa. 
Tutkijat tosin käyttävät haastatteluja paljolti survey-analyysin tapaan, jolloin keskustelu diskursseista voi jäädäkin jossain määrin marginaaliin.

Tutkimuksen teoriakonstruktio on myös valittu näppärästi, mutta kapeasti. Privatisoiminen ja koulutuksen muutosprosessin kuvaus Fullanin tapaan palvelevat kyllä tutkimusrajausta, mutta eivät erityisemmin jalosta koulutusmarkkinoista eivätkä koulutussosiologiasta käytävää keskustelua. Näyttää siltä, että ensimmäisen tutkimusraportin keskeisin käsite, privatisointi, olisi väistymässä taka-alalle ja tilalle olisi tulossa muutosanalyyttisiä välineitä, joiden monipuolistumista on niinikään lupa jäädä odottamaan.

Tutkimuskohteiden tyypittely omistuspohjan, koon ja maantieteellisen sijainnin perusteella on hyvä oivallus. Tutkimuksen tulokset eivät vielä erityisen selvästi eksplikoi omistuspohjan vaikutuksia kehitykseen, mutta kehitysnäkymiin nähden tämä tarkastelu antaa viitteitä strategioiden vaihtoehdoista tulevaisuudessa. Maantieteellisten sijaintien erilaiset ominaispiirteet saattaisivat niinikään antaa enemmän mahdollisuuksia ympäristömuutosten tulkitsemiseen. Toimintaympäristöä voitaisiin tarkastella laajemmin elinkeino- ja yhteiskuntarakenteen alueellisten piirteiden näkökulmasta sen sijaan, että rajaudutaan pääasiassa koulutusinstituutioiden välisiin asetelmiin ja koulutussektorin sisäiseen keskusteluun eristämällä koulutusmarkkinat omaan akvaarioonsa.

\section{Markkinavetoisuuden harhaa}

Ammatillisten aikuiskoulutuskeskusten päätuote on ollut työvoimapoliittinen koulutus. Markkinoille suunnattujen palvelutoimintojen osuus on kasvanut, mutta oikeastaan yllättävän hitaasti. Ammatilliset aikuiskoulutuskeskukset eivät vielä ole markkinavetoisia laajasti ymmärrettynä. Markkinat tarkoittavat niille vielä etupäässä työvoimahallinnon ostokäytäntöä. Matka monisuuntaiseen markkinajärjestelmään on pitkä. Tutkimushankkeen kannalta tämä on ollut varmaankin etu: kehityskaarta on kiitollista seurata, mutta yllättävän vähän tutkijat saavat irti aikuiskoulutuskeskusten markkinaorientaation primitiivisyydestä.

Muutosprosessi on lisännyt henkilöstön kustannustietoisuutta ja toimintatapojen taloudellisuuden arvioimista. Markkinaohjautuneemmaksi muuttunut toimintaympäristö näyttää aiheuttaneen toistaiseksi voimien keskittämisen tulosyksikköajatteluun ja organisaation muokkaamiseen. Suoraan opetukseen ja koulutukseen liittyvät strategiapohdinnat näyttävät tutkimuksen mukaan olevan vuorostaan nousemassa esiin. Muodit ja puhunnat tavoittavat kaikki koulutussektorin instanssit vuoron perään.

\section{Aikuiskoulutuskeskukset koulutushierarkiassa}

Sekä aikuiskoulutuskeskusten henkilökunnan että ulkopuolisten arvioijien opetuksen tasoa, laatua ja vaikuttavuutta arvioivan ranking-listan kärjessä ovat yliopistojen ja korkeakoulujen täydennyskoulutuskeskukset. Ammatilliset aikuiskoulutuskeskukset saavat sijoituksensa teknillisten oppilaitosten ja suurten palvelualaoppilaitosten jälkeen. Imagorakenteet ovat pysyviä ja seuraavat organisaatioiden asemaa koulutushierarkiassa. Tutkimusasetelmassa tosin aikuiskoulutuskeskusten henkilökunta ei saanut sijoittaa omaa laitostaan listalle.

Oppilaitosten yhteistyön organisoiminen näyttää ongelmalliselta. Palkitsemisjärjestelmää ei tähän ole olemassa, joskin verkostoitumisidean palkitsevuus markkinoilla oletettavasti ajan myötä näyttäytyy myös ammatillisille aikuiskoulutuskeskuksille. 
Tutkimustulosten mukaan on odotettavissa, että aikuiskoulutuskeskuksissa työvoimapoliittisen koulutuksen suhteellinen osuus vähenee. Paikallishallintoriippuvuus ja markkinoiden laajentaminen ovat etsimässä uutta tasapainoa, jolloin pohditaan erikoistumisen ja monialaisuuden etuja ja haittoja suhteessa markkina-alueen kokoon. Paikallishallintosidos myös torjuu teoreettisia ajatuksia keskusten konkurssimahdollisuuden toteutumisesta edes vaikeana aikana. Tutkijat ovat tällä konkurssikysymyksellään ilmeisesti halunneet kokeilla reaktioita todellisen markkinatilanteen toteutumiseen.

Tutkimushanke on tuottanut runsaasti yksittäisiä tuloksia ja havaintoja, joita ei tässä ole tarpeen referoida. Sen sijaan voidaan sanoa, että se liikkuu kiinnostavan laboratorion sisällä ja ympäristössä. Yleisiä suuntia voidaan peilata muiden koulutusorganisaatioiden muutoksiin. jotkut ovat markkinaorientaatiossaan paljonkin tutkittavia edellä, jotkut ovat vielä jäljessä.

Kun oletamme, että tutkimusprojekti vielä laajentaa teoreettista perspektiiviään ja koulutuspoliittista viestiään, myös markkinajohtoisuuden luonnetta syvemmin pohdiskellen, käsissämme tulee olemaan ajatuksia herättävä tutkimuskokonaisuus. Jo nyt ilmestyneiden raporttien anti on aikuiskouluttajaväelle ja koulutusstrategeille hyvin hyödyllinen vertailumateriaali. Teksti on sujuvaa luettavaa ja haastaa tuloksillaan lukijaa pohdiskelemaan oman organisaationsa tilaa ja koulutusmarkkinoiden kehityksen vaihtoehtoja.

Ossi Tuomi 